\title{
O REFÚGIO ESQUIVO: NIETZSCHE E HEIDEGGER SOBRE ARTE E NIILISMO
}

Claudia Drucker*

SÍNTESE - Tanto Nietzsche como Heidegger consideram o nilismo uma ameaça, mas divergem quanto à definição do fenômeno e quanto à resposta a ser dada. Heidegger reluta em apontar uma saída, seja através da arte ou da ação, já que também as soluçōes propostas podem ser formas de reforçar o niilismo.

PALAVRAS-CHAVE - Técnica. Vontade de poder. Auto-engano.
ABSTRACT - Both Nietzsche and Heidegger view nihilism as a great threat. However, they define "nihilism" in different ways, and disagree regarding what is to be done. Heidegger hesitates to take art and action as a way out. Art and action might strenghthen nihilism instead.

KEY WORDS - Technique. Will to power. Selfdeception.

À primeira vista, Heidegger parece ser um entusiasta da arte. Existem, porém, vários tipos de arte e modos de concebê-la. Há formas niilistas de conceber a criação - a de Nietzsche, por exemplo. A recusa da estética nietzscheana é um capítulo importante dentro do percurso do próprio Heidegger. A estética de $\mathrm{Ni}$ etzsche é coerente com o teor geral do seu pensamento, que é de vitalismo e triunfalismo exacerbados. Mas o triunfalismo é uma das formas do nilismo, uma forma que consiste em dizer a si mesmo que se está imune ao niilismo. A recusa da estética nietzscheana também é o prenúncio da filosofia heideggeriana da técnica. Neste contexto reaparece a suspeita que a arte talvez não seja, necessariamente, o antídoto do nilismo. $\mathrm{O}$ que podemos ter é algo mais modesto: uma arte que não transmita a certeza inabalável de estar isenta de nilismo.

\section{O enredamento do niilismo em si mesmo}

Nesta seção, reconstruo a leitura heideggeriana de Nietzsche, dando ênfase à tese que vivemos hoje a experiência de um eterno retorno do mesmo ou eterno presente. A partir de 1936, e pelos anos seguintes, Nietzsche é o interlocutor prin-

* Doutora. Professora. Departamento de Filosofia da Universidade Federal de Santa Catarina.

\begin{tabular}{|l|l|l|l|l|l|}
\hline VERITAS & Porto Alegre & v. 49 & n. 1 & Março 2004 & p. 5-22 \\
\hline
\end{tabular}


cipal de Heidegger, o que é atestado pelo simples volume das suas publicações.' Uma das razões para este interesse é, decerto, a comunidade de projetos filosóficos entre os dois pensadores. O propósito de Nietzsche foi desde sempre o de restituir a este mundo a sua dignidade. Queria reivindicar a finitude humana, não superá-la, como foi o propósito da teologia e da metafísica. Desde muito cedo, este programa recebe o nome de "inversão do platonismo". Já em 1870 ou 1871 Nietzsche escreve: "Minha filosofia [é] um platonismo invertido: quanto mais afastada do ser verdadeiro, mais pura, fina e melhor ela é. Viver na aparência como um propósito". ${ }^{2}$ Platonismo aí não significa apenas a doutrina de Platão. Significa também o modo como ela foi absorvida pelo Helenismo e pelo Cristianismo. Em linhas gerais, nomeia a desvalorização do mundo, da aparência e do corpo, em nome de coisas mais reais e mais elevadas - como o além-mundo, o ser e o espírito. Não é surpreendente que Heidegger se identifique com esse antiplatonismo, já que sua desconstrução da ontologia tradicional também toma o caráter mundano e finito do estar-aí como solo.

O sentido deste programa, porém, não é imediatamente visível. Muitos anos de reflexão foram necessários a Nietzsche para descobrir o que queria dizer. Neste meio tempo, absorveu pensamentos de inúmeras fontes - idealistas, céticas, nominalistas, positivistas etc. Emulou o estilo de Montaigne e de La Rochefoucauld. Estes experimentos já deram, e continuam a dar matéria para muitos estudos críticos, mas isto prova apenas que o caráter provocador do seu pensamento nem sempre é totalmente claro. A inversão do platonismo, tal como Nietzsche a deseja, não significa a adoção de qualquer posição já disponível na história da filosofia. Em outras palavras, quando se trata de interpretar Nietzsche, é preciso ser altamente seletivo - mas apenas para que possa emergir o seu pensamento propriamente dito.

Darei ênfase à visão que o pensamento de Nietzsche propriamente dito emerge, quando ele desperta para a temática da superação do niilismo. ${ }^{3}$ Heidegger acabou se decidindo por ler Nietzsche de trás para frente, no sentido em que o primeiro programa é traduzido nos termos de superação do niilismo. O critério adotado justifica o peso relativo dado às diversas obras. Nem todos os livros de Nietzsche têm interesse intrínseco, mas apenas aqueles em que os conceitos fundamentais da sua filosofia são formulados. A ênfase recai sobre a última fase. Assim é que a última fase pode ter começado com Aurora, pois aí se anuncia pela

Neste estudo, vou me limitar aos escritos que o próprio Heidegger fez publicar em vida: Heidegger, M., Nietzsche (Pfullingen: Neske, 1961, 5. ed. 1989), 2 v.: "Nietzsches Wort: 'Gott ist tot'"., começado em 1943, em Holzwege (Frankfurt a. M.: Vittorio Klostermann, reimp. 1980), pp. 205:206; "Wer ist Nietzsches Zarathustra?", começado em 1953, em Vorträge und Aufsätze (Pfullingen: Günther Neske, reimp. 1990), p. 97-122, o curso de 1951-2 Was heisst denken? (Stuttgart: Reclam, 1992). Daqui em diante, todas as citações foram traduzidas por mim, exceto quando indicado.

. Meine Philosophie umgedrehter Platonismus: je weiter ab vom wahrhaft Seienden, um so reiner shöner besser ist es. Das Leben im Schein als Ziel. Citado por Heidegger, Nietzsche, v. 1, p. 180. Kritische Studienausgabe. Colli, Giorgio e Montinari, Mazzino (org.). Berlim e Nova Iorque: 1999, v. 7. p. 199.

3 Heidegger, M. Nietzsche, v. 1, p. 232. 
primeira vez o pensamento do eterno retorno. ${ }^{4}$ Mas também começa com a primeira e segunda partes de Assim falou Zaratustra, já que aí se anunciam o superhomem, a vontade de poder e o niilismo. De qualquer maneira, ela se estende até os anos de 1887 e 1888, que teriam sido os anos durante os quais "Nietzsche atingiu a máxima clareza e paz de pensamento". ${ }^{5}$

Questiona-se 0 fato de ele não impugnar a compilação $A$ vontade de poder. Desde 1956 Schlechta já havia optado por dissolver o material correspondente na obra póstuma, arranjada em ordem cronológica. ${ }^{6} \mathrm{Na}$ época, foi uma manobra para desnazificar Nietzsche, já que a obra foi reivindicada por Elisabeth Nietzsche, como uma espécie de prenúncio da ideologia nazista. Hoje em dia, a edição Coli e Montinari tampouco inclui uma obra com o título $A$ vontade de poder. Considerarei que, embora a discussão sobre a existência ou não de um livro chamado $A$ vontade de poder, cujo primeiro capítulo se deveria intitular "O niilismo europeu" possa ser importante em algum contexto, no presente estudo é irrelevante, já que estamos tomando a obra de Nietzsche como um conjunto. Apesar de Nietzsche ter renunciado a escrever uma obra com o título $A$ vontade de poder, daí não se segue que tenha abdicado do conceito. ${ }^{7}$ Podemos dizer que o mesmo vale para outros conceitos como "transvaloração" e niilismo: embora eles sejam tematizados em fragmentos póstumos mais freqüentemente do que nas obras publicadas, o seu papel não deixa, por isso, de ser central.

É claro, porém, que a plausibilidade de todas essas escolhas só pode ser melhor aferida depois de entrarmos em maior detalhe sobre a interpretação heideggeriana. Usar argumentos técnicos para dirimir o poder esclarecedor de uma interpretação é esquecer tudo o que é mais importante. Aceitemos a hipótese que a tarefa da filosofia é anunciar o advento do nilismo e da possibilidade da sua superação, para ver se ela resulta em uma leitura plausível e interessante da obra nietzscheana. O que é niilismo? Nietzsche refere-se ao nilismo, às vezes em sentido estrito, às vezes em sentido amplo. ${ }^{8}$ Em sentido amplo, niilismo é o nome para a civilização, em geral, até hoje - desde a China e a Índia até a Europa. Todas elas se baseiam na desvalorização desse mundo, e no anseio por um outro mundo. São, em última instância, baseadas no anseio pelo nada, já que não existe um alémmundo. Abaixo, discutirei como Nietzsche justifica a universalidade do modelo niilista e ascético de civilização. Por enquanto, basta constatar que, até hoje, não

Heidegger, M. Nietzsche, v. 2, p. 258.

Heidegger, M. Nietzsche, v. 1, p. 486.

Cf. Friedrich Nietzsche: Werke und Briefe, Hanser Verlag, v. 3

NABAIS, Nuno. O papel da ideia de eterno retorno na génese do projecto de transmutação dos valores, p. 133. Em: Nietzsche: cem anos após o projecto "Vontade de Poder-transmutação de todos os valores". MARQUES. António (org.). Lisboa: Vega. A segunda versão da edição Kröner, também conhecida como Grossoktavausgabe, é a usada por Heidegger. Ela inclui a compilação organizada pelo editor testamenteiro de Nietzsche, Peter Gast, segundo os vários planos esboçados pelo próprio autor, e que podem ser consultados no volume XVIII da segunda seção, p. 413-467. O próprio Nietzsche desistiu do livro, daí a longa controvérsia sobre se devemos aceitar ou não a compilação feita por ele como legítima.

HEIDEGGER, M. "Nietzsches Wort: 'Gott is tot'", p. 219. 
se tem notícia de nenhuma civilização não-niilista, ou seja não-ascética. Nesta acepção, também pode se chamar ascetismo.

No caso particular da Europa, esses valores fundantes são representados pelo platonismo, ou seja, pela divisão do mundo em dois: um supra-sensivel ou inteligível, e um sensível ou aparente. O primeiro deve servir de padrão, medida e finalidade ao segundo. Além disso, é singular um advento que abalou a cosmologia platônico-cristã. No terceiro ensaio da Genealogia da moral, Nietzsche se refere à crise provocada pelo Esclarecimento: "desde Copérnico, o homem parece ter caído em um plano inclinado - ele rola, cada vez mais veloz, para longe do centro". 9 Desde o advento da secularização, o homem foi tirado do seu lugar especial, equiparado aos macacos, de tal forma que só pode estar cansado e enojado de si mesmo. Cultivamos hoje o autodesprezo. O mundo supra-sensivel perdeu o seu poder de iluminar e dar sentido à vida. Este é o sentido da sentença "Deus morreu". ${ }^{10}$ A Europa não pode mais voltar às suas certezas teológicas, ainda que não tenha colocado outras certezas no seu lugar. O problema é que, quando o mundo supra-sensível perde o sentido, o mundo inferior perde o sentido também. A vida nesta terra deixa de ser um período de teste e uma passagem para um mundo mais permanente. A distinção entre dois mundos rebaixava o mundo sensível, mas ao menos dava-lhe um valor e sentido, ainda que derivados e refletidos. Daí surge o niilismo europeu, o niilismo em sentido estrito, "como conseqüência necessária dos ideais até aqui: a absoluta falta de valor." ${ }^{11}$ Fala-se aqui do estado de espírito da Europa às portas do século XX, ou seja, do sentimento de que nada tem sentido. O nilismo europeu surge da abolição do vínculo íntimo entre o mundo sensivel e o inteligível, e da impossibilidade de encontrar algum valor e sentido no mundo. O niilismo em sentido estrito é, portanto, um fenômeno estritamente europeu. Não obstante, é a conseqüência direta de um processo prévio.

O caráter único do niilismo europeu não significa que é um evento gratuito. Ao contrário, existe uma relação intima entre os dois sentidos: se, no começo da história ocidental, não tivesse havido uma orientação no sentido dos valores supremos que compensavam pela falta de um valor mundano intrínseco, não haveria mais tarde um sentimento de desorientação. A convicção de que nada faz sentido é apenas a culminação necessária de séculos de desvalorização do mundo. ${ }^{12}$ É no mínimo curioso que uma filosofia caracterizada por negar qualquer tipo de ideal ou finalidade mencione algum tipo de necessidade histórica. E no entanto, é exatamente o que se afirma: "o que conto aqui é a história dos próximos dois seculos. Descrevo o que não pode se passar de outra maneira: o advento do niilismo. Essa história já pode ser contada, pois aqui trabalha a própria necessidade. Esse futuro

\footnotetext{
S NIETZSCHE, F. Genealogia da moral, KSA 5, p. 176, trad. Paulo César de Souza (São Paulo: Brasiliense, 1987), p. 176.

10 NIETZSCHE, F. A gaia ciência, seção 125, KSA 3, p. 481, trad. Paulo César de Souza. São Paulo: Cia. das Letras, 2001, p. 148. modificada.

11 NIETZSCHE, F. KSA 12, p. 339

12 NIETZSCHE, F. KSA 12, pp. 292, 309
} 
fala em centenas de sinais, esse destino se anuncia em toda parte". ${ }^{13}$ É aqui que se levanta um desafio para o leitor, uma exigência de que ele entenda porque os ideais ascéticos estão fadados a perder o seu poder. O niilismo europeu não é um acaso nem um desvio estranho, mas apenas uma antecipação do que está fadado a acontecer: "toda valoração moral pura (como por exemplo o budismo) termina em nillismo: é o que espera a Europa! ${ }^{n 4}$ Nietzsche considerou, desde muito cedo, o presente como um "momento de inflexão e um vértice da assim chamada história universal" só comparável ao advento do racionalismo socrático. ${ }^{15}$ Todas as regras que valeram até hoje começaram a desmoronar e têm que desmoronar: eis o que se afirma desde o seu primeiro livro, e se repete desde então.

- Para entender essa necessidade histórica que leva ao fim de toda cultura negadora do mundo, da terra e do corpo, é preciso levar em consideração um tema central do pensamento de Nietzsche: a sua adoção inequívoca do ponto de vista do Todo. No começo, este Todo chama-se "devir" e "vontade". Nos últimos anos, chama-se "vida" e "vontade de poder". Abaixo, estes termos serão usados de maneira intercambiável. Em algum contexto pode ser muito importante distinguir entre vida, devir, vontade de poder e vontade, mas não no presente estudo. 0 contraste principal a ser feito aqui, é que todas estas coisas ocupam o lugar do Todo. Se este Todo é uma unidade, ou se ele é uma soma de inúmeros pequenos centros, não importa. O importante é que o homem não dirige o Todo. Este pensamento não é antropomórfico, porque não é antropocêntrico. A meu ver, não se pode entrar, realmente, na filosofia de Nietzsche sem reconhecer que o sujeito humano tem apenas um papel derivativo nela. O ponto de vida do Todo se insinua sempre que nos aprofundamos nos conceitos centrais deste pensamento. Embora, às vezes, o sujeito tenha um papel importante, esta importância logo é relativizada.

Já em $O$ nascimento da tragédia, Nietzsche subordinara o humano ao cósmico, e mesmo depois de recusar, em parte, o seu primeiro livro, não volta atrás neste ponto. Só os indivíduos são perceptíveis, mas nem por isso totalmente reais. Para tudo o que se segue, é importante salientar que "indivíduo" é uma noção muito ampla, que abriga qualquer ente, inclusive "abstrações" como a cultura. Fenomenicamente, o que há é uma pluralidade de indivíduos, humanos e não humanos, embora "no fundo", a pluralidade seja apenas um véu lançado sobre o que verdadeiramente permanece, e que é um só. O devir ou vontade é o "único sujeito verdadeiramente existente" ${ }^{16}$ Diante da crueldade da natureza e da injustiça da história, o indivíduo é frágil, efêmero, e impotente. Ninguém apaga a crueldade e a arbitrariedade do mundo. O que podemos fazer é reconciliarmo-nos com esses aspectos, ou seja, aceitar a nossa própria morte. Devemos abandonar o

\footnotetext{
NIETZSCHE, F. Prefácio. KSA 13, p. 186. Cf. também p. 56.

NIETZSCHE, F. KSA 12, p. 318.

15 NIETZSCHE, F. O nascimento da tragédia ou Helenismo e pessimismo, KSA 1, p. 100. Guinsburg, J. (trad.). São Paulo, Cia das Letras, 1998, p. 94.

${ }^{16}$ NIETZSCHE, F. O nascimento da tragédia. KSA 1, p. 47. Trad, p. 47.
} 
ponto de vista do indivíduo, se quisermos nos reconciliar com a vida. No caso do individuo humano, o seu único consolo é resignar-se com o fato de que o todo permanece. Esta reconciliação também é uma forma de reforçar o triunfo do Todo. O Todo se reafirma com o auto-sacrifício dos indivíduos: ela afirma a sua própria eternidade, por sobreviver ao fim dos seus filhos. O auto-sacrifício do indivíduo coroa o triunfo da vida, e por isso mesmo a autodestruição pode ser recebida com júbilo dionisíaco. Para o Nietzsche do Nascimento da tragédia, o sentido último e central da tragédia é a celebração desta reabsorção final e voluntária do homem no Todo. Não é dado aos seres humanos um papel diferente. O que podemos fazer é apenas evitar o nojo e o horror diante da nossa impotência fundamental, não superá-la.

Mais tarde, o que permanece é a vontade, mesmo quando o homem e as outras coisas perecem, como lei suprema. A vontade existe, como maneira de o real se realiza, ou seja, como impulso para a auto-superação. O impulso para a autoexpansão é o que dá a todos os fenômenos a sua marca. O querer explica desde a fagocitose até o movimento das ondas do oceano. ${ }^{17}$ A vontade passa a ser a característica comum a tudo o que é: tudo o que é, pelo simples fato de ser, quer alguma coisa. A auto-superação é um fim em si mesmo do processo, descontados todos os outros propósitos. Apesar de "vida" e "vontade" não serem exatamente sinônimos, no que se segue, eles vão ser usados como equivalentes, pois as características que Nietzsche dá à vida são exatamente as da vontade. É, portanto, de um ponto de vista peculiar, metafísico, que devemos compreender o conceito nietzscheano de vida. $\mathrm{O}$ aumento da vida é uma espécie de lei intrínseca que se impõe a outras. A grande quantidade de aforismos intitulados "anti-Darwin" na obra póstuma de Nietzsche referem-se exatamente ao fato de ele conceber a vida, antes de mais nada, como busca de intensidade e de auto-superação: "Todas as coisas grandiosas trazem consigo a sua própria destruição através de um ato de auto-superação; assim quer a lei da vida, a lei da necessidade auto-superação que é da essência da vida". ${ }^{18}$ Darwin representa na obra de Nietzsche a visão da vida como instinto de autopreservação - mas havendo conflito entre este imperativo e o imperativo de aumento de intensidade, o primeiro deve ceder.

Assim, o antiplatonismo de Nietzsche se realiza no momento da afirmação da vontade como lei universal deste mundo "do aquém". Recusa-se a oposição entre ser e devir em nome de um conceito dinâmico do ente. Mas este caráter instável e mutante se deve ao que no ente existe de vontade. Antiplatonismo não precisa ser entendido apenas como a renúncia completa a dar conta do efetivo. Se platonismo é a compreensão do efetivo como permanente, estável e contínuo, antiplatonismo pode significar também a tentativa de compreendê-lo como não permanente, não estável e não contínuo - ou seja, como querer, e neste sentido o antiplatonismo é também um antidarwinismo.

17 NIETZSCHE, F. A gaia ciência, seção 310, KSA 3, p. 546, trad. Souza, Paulo César de. São Paulo: Cia. das Letras, 2001, p. 209.

18 NIETZSCHE, F. Genealogia da moral, KSA 5, p. 410, trad. p. 183, modificada. 
Não sabemos com clareza o que é a vontade, para Nietzsche, mas com certeza não é algo que surja a partir de nós. Sua suspeita sobre a existência do livre arbítrio não é uma suspeita sobre a existência de uma vontade "em geral" - é uma suspeita que exista uma tal faculdade sob o nosso controle. A vontade existe, e pode até se expressar como faculdade psicológica, mas seria um equívoco achar que ela é antes de tudo uma faculdade da alma. Nas palavras de Heidegger, é preciso inverter esse ponto de vista: "o ser humano passa a se compreender como sujeito volitivo em primeiro lugar com base em uma experiência ainda não elucidada do ser, no sentido de uma vontade que ainda precisa ser pensada". ${ }^{19}$ Assim, se os seres humanos têm algum privilégio, não é nem o livre arbítrio nem a vontade: o livre arbítrio humano não existe, e a vontade é uma propriedade de todas as coisas. Tudo aquilo que é, quer alguma coisa. O privilégio dado aos seres humanos é de serem parte do processo por meio do qual a vontade de poder se realiza. O ser humano é o indivíduo que cria outros indivíduos. As criações humanas também são parte da vida, e não podem contrariar os propósitos desta sob pena de perder o seu fundamento.

A cultura, embora seja uma criação do Todo, pode trabalhar a favor ou contra os seus propósitos. Isto fica implícito no terceiro ensaio da Genealogia da moral, "O que significam os ideais ascéticos?" Depois de apresentar um contraste brutal entre tipos negadores e afirmadores da vida, Nietzsche se depara com a necessidade de explicar a derrotas destes por aqueles. Por que culturas negadoras da vida puderam não apenas surgir como triunfar sobre culturas aristocráticas? Mas a própria vida, apesar de tudo, trabalha nos ideais ascéticos e tem interesse neles. 0 sacerdote ascético, "este aparente inimigo da-vida, este negador - precisamente ele está entre as forças conservadoras e criadoras do 'sim' (Ja-Schaffende) da vida" ${ }^{20}$ Pois uma vontade de nada é mais útil à vida do que a total ausência de vontade. Uma vontade de nada é melhor do que um nada de vontade, porque ao menos permite à vida preservar-se. É preciso que haja uma meta que permita à vontade pelo menos conservar-se. O ideal ascético, que é a forma concreta adotada pela vontade de nada, é um artifício para a preservação da vontade ou vida, e Nietzsche afirma que a própria vida tem interesse na sua existência: "A vida luta nele [o ideal ascético], com ele e através dele contra a morte". ${ }^{11}$. No entanto, os ideais ascéticos têm um poder limitado. Se vontade de nada não destrói a vida, tampouco a intensifica.

Toda vontade necessita de um certo estágio ou patamar de onde se lançar em direção à próxima meta. Se é próprio da vontade buscar superar-se, ela precisa de metas, algo em direção a que estender-se. A vontade precisa fixar-se em configurações semipermanentes, que são as condições para o aumento da sua atividade. A intensificação do poder exige a conquista de estágios ou patamares provisórios, em função de um processo de consumo permanente. Os valores são esses pata-

\footnotetext{
HEIDEGGER, M. Nietzsche, v. 2, p. 343.

NIETZSCHE. F. Genealogia da moral, KSA 5, p. 366, trad. p. 135, modificada.

Id., ibid.
} 
mares que permitem a fixação do devir em formas semipermanentes e ao mesmo tempo a sua auto-superação. O mesmo acontece com os "valores": eles são artifícios de que a vida se vale: A própria vida está por trás das criações, e principalmente dos nossos "valores": "quando falamos em valores, falamos sob a inspiração, sob a ótica da vida: a vida nos obriga a postular valores; a vida mesma valora através de nós quando instauramos valores". ${ }^{22}$ Por sua, a mera preservação é a morte deste processo. Ela contraria o propósito mais fundamental do ente, que é a auto-intensificação. O poder dos valores supremos e ascéticos, na forma particular do cristianismo e do platonismo, se esgota, exatamente porque não foram capazes de transformar-se em uma condição de "aumento" da vida - apenas da sua preservação. O problema com os ideais ascéticos é que eles abrigam uma tensão interna, na medida em que eles nunca chegam a ser o que um verdadeiro valor deve ser, a saber, a ocasião de um ultrapassamento de si mesmo. Os valores supremos até hoje são, estritamente falando, "desvalores" (Unwerte), pois prejudicam a vida, e portanto fazem o oposto do que um valor deveria fazer. ${ }^{23}$

Não sabemos ao certo por que o tipo de civilização ascética triunfou. Talvez a vontade, no começo da civilização, tenha tomado um curso que não era o mais adequado à sua própria natureza - talvez não. O que parece, contudo, é que sabemos que presenciamos o esgotamento desse caminho: "então por que o advento do niilismo é necessário agora? Porque nossos valores até agora são aquilo que o leva até a últimas conseqüências; porque o niilismo é a lógica dos nossos valores e ideais grandiosos pensados até o fim - porque precisamos viver o niilismo para desvendar o que propriamente era o valor desses valores". ${ }^{24}$ Dizer que o "valor dos valores" só agora começa a ser desvendado, a meu ver, é o mesmo que dizer que só agora fica claro que a própria vida trabalha por trás de toda civilização e criação, embora até aqui talvez não tenha atingido os melhores resultados. Os indivíduos humanos e não humanos têm um certo papel: eles podem ser o veículo por meio do qual a vida atinge os seus propósitos, que é o da intensificação. Até hoje, porém, eles não desempenharam essa função.

Constatada essa verdade, temos que escolher entre apressar o processo de desvalorização dos valores supremos, abrindo o caminho para um novo começo, ou aceitarmos a desorientação e falta de critério sobre como devemos viver, ou seja, se vamos adotar um nilismo "ativo" ou um "passivo". ${ }^{25} \mathrm{O}$ niilismo passivo é uma tentativa incompleta de abolir a esperança numa realidade ultramundana. Niilistas passivos são os "últimos homens", aqueles que definem como feliz uma vida que é apenas previsível, confortável e desprovida de sofrimento. A alternativa que Nietzsche propõe é, evidentemente, o "nilismo ativo". O niilista ativo é aquele que apressa a queda de um mundo caduco. As palavras de Nietzsche podem ter

22 NIETZSCHE, F. Crepúsculo dos ídolos, KSA 6, p. 86. Trad. Casanova, Marco. Rio de Janeiro: Relume Dumará, 2000, p. 37

23 HEIDEGGER, M. Nietzsche, v. 1, p. 491.

24 NIETZSCHE, F. Der Wille zur Macht, Prefácio 4, KSA 13, p. 190

25 NIETZSCHE, F. KSA 12 , p. 350-351. 
sido inspiradas pelos filósofos materialistas russos, como por exemplo Dmitri Píssarev: "Numa palavra, eis o ultimato de nosso campo: o que pode ser quebrado deve ser quebrado; o que resiste ao golpe merece ser mantido, o que voa em pedaços é lixo; em qualquer caso, bata à direita e à esquerda, nenhum dano pode vir disso e nenhum dano virá. ${ }^{26}$ Mas o que torna o seu pensamento singular frente aos niilistas russos é a noção que o niilismo completo resultará na revalorização do mundo com base em um novo princípio. Atribui-se à destruição um poder criador. Um processo de destruição é sempre o começo de algo novo:

Visão do todo: de fato, todo grande crescimento vem acompanhado de um tremendo desmoronar e perecer: o sofrimento e os sintomas de declínio fazem parte dos tempos de enormes avanços. Todo movimento fértil e possante da humanidade criou também um movimento niilista. Poderia ser um sinal do crescimento mais crucial e essencial, da transição para novas condições de existência, que a forma mais extrema do pessimismo, que o niilismo genuíno, deva surgir no mundo. Isto eu compreendi. ${ }^{27}$

Assim, não só a própria exaustão dos valores supremos até aqui é um processo inevitável, mas também vai levar necessariamente a um novo começo, se for conduzido de maneira total. A meu ver, Nietzsche não encontra a mão da necessidade histórica apenas no processo que nos trouxe até aqui, mas também na necessidade de que este momento não dure para sempre. É como se algo que tivesse que acontecer. Uma visão contrária seria que o niilismo passivo pode constituir um "eterno retorno" por si mesmo - ou seja, que a necessidade histórica fica abolida e que cabe aos homens criar, se quiserem, um novo destino para si mesmos, ou imobilizar-se. Mas, a meu ver, o que prevalece no pensamento de Nietzsche ainda é a crença que o niilismo "completo" ou "genuíno" vai levar à própria superação. A vontade de poder é elevada à condição de princípio, embora até hoje reprimido, da civilização. A vontade de poder deve se tornar um princípio explícito de ação, de tal modo que a civilização se erga sobre novas bases. $\mathrm{O}$ nilismo ativo nega tudo - ou seja, nega toda a interpretação do ente tal como conduzida até aqui, para abrir o caminho para uma nova afirmação.

O que viria depois da consumação do niilismo? Em que consiste esta nova afirmação? Só podemos imaginar como seria um mundo e uma civilização que tomassem este mundo como orientação. A visão de Nietzsche para um mundo governado pela vontade de poder, tal como reconstruída por Heidegger, pode ser resumida muito sucintamente nos seguintes termos: não há um mundo transcendente, pois não há nada acima deste mundo e distinto dele. Tampouco este mundo é limitado, na medida em que ele está sempre visando um ultrapassamento de si mesmo. A inversão do platonismo significa a "transformação do "inferior", ou seja, do sensivel, em "vida" no sentido da vontade de poder" ${ }^{28}$ Nada permanece o mesmo; tudo está em movimento. A doutrina dos dois mundos é substituída por

\footnotetext{
${ }^{26}$ PÍSSAREV, Dmitri. Ensaios (Moscou: 1955), v. I, p. 135. Apud FRANK, Joseph. Dostoiévski: Os efeitos da libertação 1859-1865. Trad. Souza, Geraldo Gerson de. São Paulo: Edusp, 2002, p. 249-50.

27 NIETZSCHE, F. KSA 12, p. 468

${ }^{28}$ HEIDEGGER, M. Nietzsche, v. 2, p. 170.
} 
uma em que o devir é a única lei. Nietzsche anuncia o advento futuro do "grande meio-dia", ou seja, do momento em que nada lança sua sombra. Não existe nem recolhimento nem mistério. Heidegger aponta a interdependência entre os conceitos de vontade de poder e eterno retorno do mesmo. ${ }^{29} \mathrm{O}$ devir é explicado como eterno retorno, no sentido em que não ruma em direção ao totalmente outro. Quando toda noção de um além-mundo foi abolida, o devir se afirma a si mesmo. A vida é eterno retorno do mesmo, mas este mesmo que retorna, não é nem totalmente o mesmo nem totalmente outro. O mesmo retorna como mais vida, e, ao mesmo tempo, querer ser mais intensa já é a característica própria da vida. O eterno retorno do mesmo, por sua vez, tem um elemento de vontade de poder. A vida aparece como algo movido a partir de um imperativo para ir além, incessantemente. Este imperativo poderia tomar o seu impulso apenas de algo como uma vontade, já que a vontade é movimento auto-impulsionado. O que retorna sempre é a própria vontade. O grande meio-dia é uma imagem para o que acontece com os indivíduos depois da inversão consumada do platonismo: exposição total, e ao mesmo tempo perda de qualquer dimensão de profundidade. $O$ ente não deve opor resistência, é necessário que ele não insista em manter nenhuma característica individualizante, para que o processo prossiga. Se o tempo é a própria forma da experiência, o tempo vivido como eterno retorno do mesmo desabriga todos os entes como simples fundo de reserva. Quando a vontade ilimitada impera, todo repouso é apenas uma pausa na direção do próximo lançamento. Mais do que isto, todo repouso tem que passar. Tudo tem que passar para que só o próprio devir permaneça.

Ao negar completamente tudo o que foi até aqui e ao preparar o advento de um novo princípio civilizatório, o homem também nega a si mesmo em favor de um outro tipo. Qual foi até hoje a marca distintiva da humanidade? A racionalidade, mas a racionalidade entendida como não aceitação do corpo e das paixões. A animalidade foi até hoje o oposto da humanidade ${ }^{30}$ Isso significa, no pensar de Nietzsche: o homem até hoje buscou na razão uma explicação e uma justificação para a vida. A vida sempre teve que ser justificada, pois em si mesmo parecia resistir a qualquer explicação racional. A vida parecia abrigar o mal. A razão humana sempre buscou a teodicéia, muito antes de o nome ter sido cunhado por Leibniz. Por conseguinte, o humano será superado quando não mais for preciso justificar a vida, quando a vida não for mais sentida como má. O alinhamento da vontade humana com a vontade cósmica será expresso e buscado, e o último resquício de mal-estar e revolta será apagado. $\mathrm{O}$ amor fati será levado às últimas conseqüências, significa que não apenas resignamo-nos com o que é, mas também o queremos, aceitando inclusive a própria destruição. $\mathrm{O}$ homem renuncia a buscar refúgio no que quer que seja, inclusive no seu ego autônomo. Aquele que já não busca redenção de nenhum tipo, que não opõe resistência alguma, ao ponto de transformar-se no próprio sentido da terra, já não pertence à espécie que

29 HEIDEGGER, M. "Nietzsches Wort", p. 233.

30 HEIDEGGER, M. Nietzsche, v. 2, p. 294. 
conhecemos. A marca dessa nova espécie é afirmar a vida incondicionalmente, não recuando diante de nenhum dos seus aspectos absurdos e asquerosos. A sua vontade é uma só com a vontade cósmica. O super-homem pode ser definido não principalmente como aquele que se afirma, mas como aquele que afirma o triunfo esmagador da vontade poder no seu próprio existir: "o 'super' no substantivo 'super-homem' contém uma negação e significa o ir adiante e ir além 'por sobre' (über) o homem atual. O não nesta negação é incondicional, na medida em que provém do sim da vontade de poder" ${ }^{31}$ Assim, a marca do super-homem é negar o que até hoje foi a marca distintiva da humanidade, de modo a tornar-se capaz de um sim incondicional à vida.

Até aqui, trata-se de uma interpretação. Mas Heidegger não se limita a interpretar. Refiro-me aqui à famosa "confrontação" em que sua interpretação acaba. ${ }^{32}$ A confrontação gira, a meu ver, em torno da suspeita que o niilismo, não tenha, por si mesmo, nenhum potencial de recomeço e redenção. O novo estágio da história, marcado pela noção de que não há nada além deste mundo, caracterizase pelo voltar-se sobre si mesmo do tempo. Não existe nada além do já dado, nenhuma possibilidade diversa além da consumação contínua do que já está vigorando. Neste sentido, o fim do platonismo não significa um novo começo. O niilismo não é uma transição para um começo novo. A consumação do nilismo consiste apenas no seu enredamento (Verstrickung) em si mesmo: "por meio do enredamento do niilismo em si mesmo, o niilismo se torna pela primeira vez totalmente acabado como aquilo que ele é" ${ }^{33} \mathrm{~A}$ inversão do platonismo não levou a uma nova época da história, marcada pela valorização da terra, dos sentidos e do homem: "tudo o que Nietzsche quis atingir com seus escritos transformou-se no seu contrário" ${ }^{34}$ Contra a sua intenção inicial, as categorias que ofereceu para pensar o sentido da Terra e da finitude humana não constituem uma ruptura com a desvalorização deste mundo. É da natureza do nilismo consumado enredar-se em si mesmo, porque não leva à sua própria superação. A consumação do niilismo significa a continuidade do processo de uso e esgotamento contínuos do real.

\section{Arte e niilismo}

Tentemos tornar um pouco mais plausivel a noção de que Nietzsche atingiu o oposto da sua intenção inicial, e que a valorização do mundo transformou-se no seu aniquilamento. Para isso, retomemos por um momento a visão de Nietzsche sobre a arte em $O$ nascimento da tragédia. Vimos que o devir é insensível ao sofrimento dos indivíduos a que dá à luz. A natureza não se importa com o perecer dos espécimes, pois ela mesma não é afetada. Mas, se os indivíduos são meras ilusões fugazes, e se o ponto de vista do todo os torna supérfluos e sem importân-

31 HEIDEGGER, M. Nietzsche, v. 2, p. 292.

32 HEIDEGGER, M. Nietzsche, v. 1, p. 13.

33 HEIDEGGER, M. Nietzsche, v. 2, p. 340.

${ }^{34}$ "Alles, was Nietzsche mit seinen Schriften erreichen wollte, sich in das Gegenteil verkehrte." HEIDEGGER, M. Nietzsche, v. 1, p. 474. 
cia, qual o seu sentido? De fato, o devir não é totalmente insensível à sorte dos indivíduos, embora os destrua sem piedade. Curiosamente, ele tem interesse em criar uma pluralidade ilusória. A individuação é o que torna algo visível. Ela salva algo da indiferenciação resultante do fluxo contínuo e devorador do devir. A própria natureza não deixa de ser uma ficção. A regularidade, a permanência e o brotar são delimitações sempre um tanto arbitrárias de um movimento constante. O devir deseja a existência de uma pluralidade, ainda que parcialmente falsa. A vida tem interesse em que algo se destaque e se diferencie. Isso é o que salva o devir de ser um fluxo selvagem e indiferenciado. Todas as belas formas são interessantes ao devir. A vida tem necessidade de configurações ("máscaras", "ideais"). As realizações humanas, assim como a natureza, tornam isso possível. A arte surge, em parte, do impulso "apolíneo" de criar modelos e configurações - um impulso do homem que satisfaz um impulso do próprio devir. Através do criador humano de belas máscaras, o devir (que é o verdadeiro criador, por trás de nós) realiza o seu desejo de preservar alguma coisa do seu próprio movimento devorador às formas criadas pelos indivíduos. Através do artista, é a própria vida quem cria. Uma maneira de entender a noção que a arte é "a atividade propriamente metafísica desta vida" é essa. ${ }^{35}$ Tanto o impulso apolíneo dos indivíduos para destacar-se, quanto o seu impulso dionisíaco para a reunião com o Todo são interesses do próprio devir.

A beleza não é algo acrescentado aos indivíduos, mas um aspecto intrínseco seu. Brilhar, ressaltar, mantendo-se dentro de limites, é a marca tanto do ser como do aparecer, tanto do ser como do ser belo. O indivíduo, é o que tem figura, o que tem contornos diferenciados e se mantém dentro deles. $\mathrm{O}$ indivíduo é aquilo que se mantém no brilho da aparência, nem que seja por um instante fugaz. Ele escapa da indiferenciação e da obscuridade que são a marca do devir. A doação de figura insere, por um momento, um pouco de delimitação e permanência no fluxo constante de criação e destruição que é próprio da vida, e isso é o mesmo que criar a beleza. Aquilo que adquire um aspecto nítido, que ressalta e brilha é, para os gregos, o belo. Isso se diz dos indivíduos naturais e dos criados. A criação do belo dá aos indivíduos, por um instante o dom da diferenciação, do aparecer, do ressaltar - em uma palavra, o dom de ser - e por isso interessa ao devir. O devir, isto é, o real sujeito do pensamento nietzscheano, tem um interesse estético nos indivíduos, sejam eles naturais ou criados. Todas as obras humanas podem se dizer frutos da necessidade que a vida ela própria tem de metas e ideais. Embora a destruição seja uma lei universal, o amor à beleza -que em certo sentido é o seu oposto - também é um fenômeno universal.

Existem indivíduos humanos e não humanos. Todos são veículos por meio dos quais a própria vontade se afirma. Mas os indivíduos humanos têm o privilégio de intensificar o processo de intensificação da vontade. Apesar de Nietzsche retirar o homem do lugar central, e apesar de adotar sempre o ponto de vista do To-

35 NIETZSCHE, F. O nascimento da tragédia, KSA 1, p. 24, trad. p. 26 
do, os criadores têm um papel especial. Eles fixam os indivíduos e as belas formas, a partir de um impulso ditado de fora para dentro, num processo contínuo. 0 devir, o único sujeito realmente existente, continua a ter um interesse na criação de figuras. O devir tem um interesse puramente contemplativo na existência do belo, no pensamento de $O$ nascimento da tragédia. Este interesse cede o lugar ao interesse da vontade de poder na sua intensificação. O homem passa a ser um criador de valores, no pensamento tardio de Nietzsche, assim como o devir levava o artista, em $O$ nascimento da tragédia, à criação do belo. Para que servem valores? Os valores são uma condição para a intensificação da atividade vital: "o ponto de vista dos 'valores' é o ponto de vista das condições de preservação, aumento com respeito a formas complexas de duração relativa dentro do devir" ${ }^{36}$ Nenhum indivíduo tem uma configuração permanente. Nada permanece o mesmo. Agressiva e espontaneamente, todas as coisas buscam ir além de si mesmas, porque visa o seu próprio ultrapassamento. O ente é dinâmico; mas isto é compreendido no sentido de um querer. Este é o traço comum a tudo o que existe: a vontade. Por outro lado, não ter nenhum forma estável impediria as coisas de expandir-se, o que é o seu objetivo.

É assim também com todas as obras humanas. Apagam-se quaisquer diferenças importantes entre entes naturais e criados, e também as diferenças entre os diversos entes criados. A vontade de poder pode se apresentar sob a forma das "leis naturais", da vida, da arte, da política, da religião, do Estado e do conhecimento. ${ }^{37} \mathrm{O}$ Estado e todas as instituições que constituem uma civilização brotam, em última instância, da necessidade que o próprio devir tem de se fixar em configurações semipermanentes. Já se falou muito sobre o fato de Nietzsche igualar arte e ciência, classificando ambas como ficções, mas a justificativa para este nivelamento nem sempre transparece na discussão. A aproximação entre arte e conhecimento se baseia, em última instância, na visão que instituições e tesouros culturais são a condição necessária da atividade típica da vida. Sem metas, a vontade não tem suas paradas ocasionais, pontos de condensação que preparam o próximo salto em direção à próxima meta. A vontade não pode se lançar adiante sem projetar como seu objetivo algumas realizaçōes. As realizações às quais os homens se lançam são como que degraus para uma intensificação potencialmente ilimitada, e por isso são "formas complexas de duração relativa dentro do devir", ou seja, patamares provisórios que permitem à vontade querer sempre mais. Uma vontade sempre exige metas. Através de nós, ou seja, através das figuras que os criadores criam, a vida obtém os ideais em direção aos quais ela pode se estender, e se intensificar. Quando os homens criam arte, religião, direito e Estados nacionais, o que eles fazem é dar à vida uma oportunidade de intensificação. Assim, a criação não está mais a serviço da reconciliação do Todo consigo mesmo mas da sua auto-superação constante. Tanto a atividade de conhecer como a de criar,

\footnotetext{
${ }^{36}$ NIETZSCHE, F. KSA 13, p. 36.

${ }^{37}$ NIETZSCHE, F. KSA 13, p. 254.
} 
como a de agir, são regidas pelo impulso "erótico" de fixar o devir em leis e formas semipermanentes e condenadas a ser ultrapassadas.

Ainda assim a arte tem um privilégio. Nietzsche a considera o grande antídoto para o nilismo, "o antiniilista (das Antinihilistische) par excellence". ${ }^{8}$ Isso se deve ao seu poder "plasmador", mas também ao estado de intoxicação e excesso que provocam. Nietzsche prefere as obras de arte que produzem mais intoxicação e considera a presença deste estado a marca distintiva da experiência estética. Por que preferir este tipo de arte e este tipo de experiência? O que está envolvido na supervalorização das experiências mais intensas? Como já se vê, a criação e a fruição estéticas são expressões da vontade. A intensidade do entusiasmo que a arte provoca no criador e no público é a finalidade do processo. A arte é antinilista, no sentido de Nietzsche, já que a experiência mais pura de afirmação da vontade. A criação é vista como entrega ao movimento da vida. Existe um prazer peculiar envolvido nesse abandono de si mesmo. Não porque em si mesmo o abandono seja prazeroso. O comentário de Freud - que uma dor de dentes já basta para deixar qualquer um de mal com a vida - mostra que ele não compreendeu o sentido deste amor à vida. A entrega total à vida não envolve repulsa à dor. Ao contrário, pode envolver muita dor, e até morte, mas tais aspectos parecem ser compensados ou redimidos pelo sentimento dionisiaco de fusão com o Todo. Assim como o jovem Nietzsche achava que o êxtase dionisíaco permitia a entrevisão confusa do fundo selvagem de onde brota toda a vida, o Nietzsche maduro considera que a fruição e criação de obras são o ponto mais próximo de uma pura vontade de poder a que podemos chegar.

Esse prazer envolvido no abandono de si mesmo a um movimento maior que nós mesmos não seduz Heidegger nem um pouco. A filosofia da criação nietzscheana reforça seu entusiasmo pelo processo de consumo universal, ou, como Heidegger o chama, de vontade de vontade. Nietzsche descreve a criação em termos que ajudam a nomear e compreender aviltamento crescente de todas as coisas, quando a descreve como a oportunidade para uma intensificação da vontade de poder, não a sua dignificação. Quando a criação, seja ela artística ou de outro tipo, é compreendida tecnicamente, ela nada tem de idílica ou libertadora. $\mathrm{O}$ ente é fagocitado, usado como degrau ou estágio para uma intensificação cada vez maior da vontade. Tudo é material para um perpétuo processo de trabalho (formação), uso e manipulação. Contra Nietzsche, Heidegger crê que não existe aí nenhum potencial de redenção e criação.

\section{A incapacidade de o niilismo reconhecer a si mesmo}

Podemos ver nos cursos sobre Nietzsche os primeiros traços da filosofia da técnica que Heidegger desenvolve a partir das Conferências de Bremen, de 1949. Aparentemente, não existe muito em comum entre a recusa do voluntarismo,

${ }^{38}$ NIETZSCHE, F. KSA 13, p. 521. 
presente nas conferências sobre Nietzsche e a técnica. Mas o sentido ordinário da técnica não é o de Heidegger. A técnica não se resume à tecnologia. A invenção de meios tecnológicos é tornada possível pelo modo técnico de mostrar o ente. A técnica, para Heidegger, é uma forma de desabrigar o ente em que determinamos de antemão o que e como vai se desabrigar. A técnica realiza uma espécie de prefixação dos fenômenos de acordo com objetivos estipulados por nós. A conferência "A pergunta sobre a técnica" abre-se com um contraste entre diferentes formas do desabrigar, ou seja, as diferentes formas como os entes se nos apresentam. O modo como as coisas se nos mostravam "antigamente" é diferente do modo da técnica. Antigamente, o camponês "entregava a semeadura às forças do crescimento e protegia o seu desenvolvimento". ${ }^{39}$ Agora, quando se trata da natureza, não se obedecem aos seus ritmos e potencialidades dadas. Ao contrário, exige-se que a natureza se comporte como nós ditamos. Por exemplo, modificamos os ciclos naturais de tal forma que eles cumpram os objetivos por nós determinado. O modo técnico de relacionar-se com os entes os desafia, porque exige que eles correspondam aos fins que nós estipulamos:

O campo que o camponês antigamente preparava se mostrava de outro modo, quando preparar ainda significava: cuidar e guardar. $\mathrm{O}$ fazer do camponês não desafia o solo do campo... também a preparação do campo entrou na esteira de um tipo de preparação diferente, um tipo que põe (stellt) a natureza. Esta preparação põe a natureza no sentido do desafio. ${ }^{40}$

O desafio precede e condiciona o modo de os entes se mostrarem, e transforma o ente em um fundo de reserva adequado, de antemão, aos fins que venhamos a determinar. O desafio tende a excluir outras formas do mostrar-se. Ele tem por definição o caráter de um projeto a priori que passa por cima de qualquer coisa que se ofereça gratuita e espontaneamente. Como não se vê nenhum impedimento visivel ao florescimento livre, imaginamos que não existe nenhuma restrição operando aí. Mas o desafio é um impedimento a todo brotar espontâneo. Ele é um modo intrinsecamente nivelador do desencobrir, que expulsa a contingência, e só produz regularidade extrema. Reduz-se radicalmente a contingência, e a possibilidade de algo não-programado surgir. A homogeneidade e regularidade crescentes são o sinal disso. O desafio transforma todas as coisas em Bestand ("estoque", "recurso" ou "fundo") que se guarda para que seja continuamente explorado. ${ }^{41}$

O que é chamado de desafio, em 1949 e 1954, é o mesmo que Heidegger chamara antes de vontade de vontade. Aquilo que reaparece alguns anos mais tarde sob o nome de Gestell ou essência da técnica recebe em Nietzsche o nome de "maquinação" (Machenschaft). ${ }^{42} \mathrm{O}$ querer que se impõe incondicionalmente se

39 HEIDEGGER, M. "A pergunta sobre a técnica". Em: Vorträge und Aufsätze (Pfullingen: Günther Neske, $6^{\circ}$ ed. 1980), p. 18, trad. Marco Aurélio Werle (Cadernos de Tradução do Departamento de Filosofia da Universidade de São Paulo, n. 2. 1997), p. 57.

40

Id., ibid.

41 HEIDEGGER, M. "A pergunta sobre a técnica", p. 17, trad. p. 61.

42 HEIDEGGER, M. Nietzsche, v. 2, p. 471. 
transforma na noção de essência da técnica - Gestell ou "enquadramento" ${ }^{43}$ Enquadrar significa retificar ou fazer corresponder a uma expectativa, o que é precisamente o que a técnica faz. Desde Kant, sabemos que toda interpretação prévia do que a natureza e o homem são, introduz regularidade e uniformidade de eventos, obras e ações, precisamente por ser prévia. O enquadramento, por exigir de antemão um certo rendimento, estimula a regularidade e uniformidade de resultados. Os mesmos procedimentos que permitem prever e controlar resultados inibem o acaso e a contingência. O ponto em comum à essência da técnica, à maquinação e à vontade de vontade é que ambas passam por cima dos entes na sua auto-afirmação.

O pensamento de Nietzsche, se é que ainda é preciso dizê-lo, não é a causa da ou uma das causas do enquadramento. No entanto, ele ajuda a nomeá-lo - e isto não é pouco. Nomear, de acordo com a visão heideggeriana da linguagem, é dar consistência. Como no verso de Stefan George: "onde falta a palavra, coisa nenhuma pode ser". Com a noção de vontade de poder e eterno retorno do mesmo, Nietzsche ofereceu a primeira imagem do processo de consumo de todos os entes, e uma especialmente vívida. Não é por acaso que é em uma conferência sobre Nietzsche que a palavra Bestand é empregada pela primeira vez no sentido de "estoque", "recurso" ou "fundo", em contraste com o sentido anterior, e bastante neutro, que a palavra recebe em Ser e tempo. ${ }^{44}$ A inversão do platonismo deixou esse traço do platonismo intocado: o ente não tem nenhuma dignidade em si mesmo. A visão nietzschiana da criação ensina a mesma atitude de busca da intensidade, que implica um abandono à instauração da vontade de poder como lei explícita de todos os eventos. Se é lícito falar em violência ontológica, em uma espécie de violência que atinge o ente no próprio modo da sua apresentação, então o platonismo - e também a sua negação, por Nietzsche - são casos desta violência. O "grande meio-dia" é uma forma desafiadora de desabrigar o ente, ao roubar dele a propriedade de surgir ao mesmo tempo empurrando para a obscuridade aquilo que não é ele. Negar ao ente a sombra de onde ele surge é negá-lo como indivíduo. Nietzsche, contrariamente à sua intenção original, endossa uma relação consumidora com o ente. Por esta razão, é o "último metafísico". ${ }^{45}$

Não há por que consolar-se ou alegrar-se com o fato de que tudo precisa ser usado e destruído para que o processo de auto-afirmação da vida prossiga. Nilis-

4 HEIDEGGER, M. "A pergunta sobre a técnica", p. 23. O termo Gestell, em que pesem as dificuldades de transportá-lo para outra língua, já foi traduzido no Brasil por Marco Aurélio Werle como "armação" (p. 65) e por Emmanuel Carneiro Leão como "com-posiçăo" (cf. Ensaios e conferências. Petrópolis: Vozes, 2002, p. 23. Com certeza, há boas razões a recomendar uma e outra escolha, mas "armação"e "composição"ainda são termos suaves para descrever o que Heidegger parece ter mente. "Enquadramento", como o inglês Enframing, tem uma nuance mais ativa e enfatiza a noção de um projeto prévio a partir do qual os entes se mostram.

44 HEIDEGGER, M., "Nietzsches Wort", pp. 225, 253. Em Ser e tempo, Bestand é o que se deixa apreender a partir de um projeto de possibilidades do estar-aí, e no entanto o projeto tem que respeitar as caracteristicas próprias daquilo sobre que se projeta. Cf. Sein und Zeit, Tübingen: Max Niemeyer, 15. reimp. 1984, p. 145.

45 HEIDEGGER, M., Nietzsche, v. 1, p. 480 
mo sempre significa destruição, mesmo quando esta destruição se dá, aparentemente, em favor da afirmação última da vida. Não há nenhuma função redentora ou afirmativa ao processo de destruição permanente. De fato, a escrita acadêmica não pode reproduzir o estado de ânimo que acompanha o pensamento contido em Nietzsche, que é de aflição profunda. O contraste com os momentos anteriores é enorme. Na década de 1930, e não apenas na Alemanha, dava-se como certo que a democracia liberal seria muito em breve suplantada por algo muito melhor, e que alguma forma de luta estava plenamente justificada diante do caráter manifestamente medíocre, provisório e instável dos corpos políticos existentes. Heidegger mergulhou neste ambiente de exaltação, e chegou a fazer o elogio da luta-sob a forma estilizada de uma luta pelo espírito do povo alemão, como transparece no discurso do reitorado. $\mathrm{O}$ autor de Nietzsche é como se fosse outra pessoa, que já não partilha a esperança de transformação radical através de nenhum estado exaltado, seja ele de criação, intoxicação ou disposição para a luta.

A ação não é, necessariamente, uma saída do nilismo, como ainda pode reforçá-lo. A ação pode ser encobridora, quando tende a minimizar a indigência. Heidegger já não aposta na ação em 1939: "a palavra 'decisão', denunciadora e quase exausta, é especialmente preferida hoje quando tudo já foi decidido ou pelo menos se pensa ter sido decidido". ${ }^{46}$ De fato, nesse momento se dá a consumação do niilismo. Ela acontece, quando aqueles que mais o disseminam já nem se dão conta do verdadeiro sentido de suas ações. A consumação do niilismo consiste na nossa progressiva aceitação da sua lógica, na nossa ausência de aflição em relação a ele. Desse modo, pode ocorrer até mesmo quando o niilismo é expressamente nomeado como "adversário": "[a]queles que se supõem isentos do niilismo são talvez aqueles que se encarregam de forma mais competente da sua difusão. Pertence à estranheza deste 'mais indesejável dos hóspedes' que ele não consegue nomear a sua origem". ${ }^{47}$

Para ser coerente consigo mesmo, o pensador não deve se colocar no lugar do profeta. Uma declaração como "só um deus pode nos salvar" não pretende ser uma proclamação. Mesmo quando Heidegger parece apostar suas fichas na ação, a própria definição de ação aí pressuposta não é muito promissora. Pode-se acreditar seriamente que "o pensamento é a forma mais alta da ação" e que "ele age na medida mesmo em que pensa?" ${ }^{\text {48 }}$ A meu ver, são declarações ocasionais que não significam que o filósofo alemão acreditou sinceramente em apontar saídas.

Nossa relação com a arte deve refletir a mesma disposição. Existem intérpretes para quem Heidegger considera a criação e fruição de obras de arte uma espécie de refúgio, como Friedrich-Wilhelm von Herrmann e Otto Pöggeler ${ }^{49}$ No entan-

${ }^{46}$ HEIDEGGER, M. Nietzsche, v. 1, p. 476.

${ }^{47}$ HEIDEGGER, M. "Nietzsches Wort", p. 214.

48 HEIDEGGER, M. "Carta sobre o humanismo". Em: Wegmarken. GA 9, p. 313. Trad. Ernildo Stein em Martin Heidegger - Conferências e escritos filosóficos (São Paulo: Abril, 1974), p. 347 e Emmanuel Carneiro Leão (Rio de Janeiro: Tempo Brasileiro, 1995), p. 25.

49 POGGELER, Otto. "Heidegger, Nietzsche and Politics". Em: The Heidegger Case -On Philosophy and Politics, ed. Rockmore, Tom e Margolis, Joseph (Filadélfia: Temple University Press, 1992), p. 
to, é preciso encarar com cuidado tais afirmações. As mesmas razões que levam Heidegger a se afastar do voluntarismo e triunfalismo nietzscheanos levam-no a desconfiar que exista sempre um contraste marcante entre técnica e arte. A técnica é uma força capaz de operar até mesmo dentro do que passa por obra de arte e por pensamento sobre a arte. Decerto é niilista toda criação a serviço do enquadramento. Os exemplos mais evidentes são a indústria cultural e toda arte que esteja a serviço de canalizar as emoções do público numa dada direção. Mas, acima de tudo, toda forma de triunfalismo serve ao enquadramento: "aqueles que se supõem isentos do niilismo são talvez aqueles que se encarregam de forma mais competente da sua difusão". Se o triunfalismo consiste precisamente em considerar-se isento de niilismo, uma forma da arte é adequada para os dias de hoje é aquela que renuncia a apontar uma saída. Aquele que promete uma saída só faz reforçar a nossa incapacidade de aflição. Por sua vez, uma arte que servisse apenas para nos despertar da nossa atual ausência de aflição, já seria o que se pede.

131. VON HERRMANN, Friedrich-Wilhelm, "Kunst und Technik". Em: Heidegger Studies. v. 1 (1985), p. 57. 